ISSN 1392-3196 / e-ISSN 2335-8947

Zemdirbyste-Agriculture, vol. 101, No. 1 (2014), p. 11-18

DOI $10.13080 /$ z-a.2014.101.002

\title{
Effects of low precipitation periods on the herbage yield of mesic semi-natural grasslands under different cutting regimes
}

\author{
Branko KRAMBERGER, Anastazija GSELMAN, Miran PODVRŠNIK, \\ Mario LEŠNIK, Dejan ŠKORJANC \\ University of Maribor \\ Pivola 10, Hoče, Slovenia \\ E-mail: branko.kramberger@uni-mb.si
}

\begin{abstract}
Climatic changes have led to extreme weather events, with longer dry periods affecting forage production in mesic grasslands. The effects of grassland management and years with periods of low precipitation on herbage dry matter (DM) yield were studied in two-long term grassland experiments with different cutting and fertilization regimes for the period 2000-2012. In both experiments, the annual herbage DM yields had high correlations with the amount of precipitation. The correlation was stronger in frequent cuttings regimes. The management type and the year significantly affected the herbage DM yield in both experiments. There was also a significant management $\times$ year interaction. On average, over the whole observation period, the herbage DM yield of equally fertilized treatments in experiment I was higher in treatments with two cuts per season than in treatments with more cuts. Furthermore, longer periods of low precipitation exerted fewer effects on the DM yield of the two cuts treatments compared to higher cutting frequencies. However, the increase in herbage productivity in years following seasons with low precipitation was higher in the treatments with higher cutting frequencies than in those with two cuts per season. When the treatment, cut four times per year, received a higher amount of fertilizer than the treatment, cut twice per year (experiment II), the long-term average annual herbage DM yield was higher and the yield was less decreased by longer periods of low precipitation than the two cuts per year treatment. Despite the fact that the effects of different treatments were proved in both experiments, the differences in the DM yields among the treatments in low precipitation years were not high enough to recommend best-management practices for forage production on mesic grasslands in areas subject to increasing periods of low precipitation.
\end{abstract}

Key words: cuts, drought, dry matter yield, grassland, precipitation.

\section{Introduction}

Climatic changes may lead to an increase in the intensity and the magnitude of extreme climatic events (Beierkuhnlein et al., 2011; Zhang et al., 2011). In particular, the result is increased rainfall variability, which is reflected in longer dry periods and more intense rainfall, with likely effects on agricultural yields in temperate grasslands (Walter et al., 2012).

It is difficult to observe simultaneously the effects of rainfall and other meteorological elements (e.g., air temperature) on plant growth because these factors are interdependent (Cong, Brady, 2012). However, Sherry etal. (2008) reported that climate warming increased plant productivity in spring if soil moisture was adequate. During summer and fall, or under spring drought conditions, moisture became the major determinant of plant biomass. In many other studies on the effects of meteorological elements on crop yield, higher impacts have also been ascribed to rainfall, rather than to air temperature (Cong, Brady, 2012). Consequently, precipitation is known to be a key driver of grassland productivity, and grassland often exhibits strong and rapid functional responses to altered rainfall patterns (Bloor et al., 2010). According to some authors (Knapp et al., 2008; Heisler-White et al., 2009; Walter et al., 2012), mesic grasslands, which are extremely important for forage production in many temperate areas of the world, show a large reduction in productivity in response to more extreme rainfall events. Consequently, much research in the last decade has been aimed to study the effects of drought on grassland productivity and responses of grassland plants.

Most of the effects of rainfall variability on grassland productivity can be attributed to altered spring rainfall variability (Walter et al., 2012). In botanically diverse grasslands, biodiversity provides a buffer against environmental fluctuations because different species respond differently to these fluctuations, leading to functional compensations among species (Tilman et al., 2006; Zavolloni et al., 2008). In temperate zones, with an adequate water supply and intensive land use, it's likely that fertilization and the cutting or grazing frequency may overcome the influence of climatic conditions 
on biomass yields (Bradford et al., 2006). However, according to Walter et al. (2012), the buffering effect of the cutting frequency on the yield seems to be small. As shown in many studies (Kramberger, Gselman, 2000; Swemmer, Knapp, 2008), changes in the cutting regime alter the community composition, and the productivity of grasslands, therefore, depends on the cutting frequency and the cutting history (Turner et al., 1993; Walter et al., 2012). As was stated by Walter et al. (2012), despite the major interest of farmers in adapting grassland management to more frequent droughts, data are lacking on the interactive effects of land-management practices (e.g., mowing frequency) and climatic changes, especially rainfall variability, on mesic grassland productivity and forage quality.

The objectives of the current study were to examine the effects of cutting frequency and years with high variability in precipitation on the herbage productivity of mesic semi-natural grassland. The study used data on herbage DM yields during the last 13 of 18 years of grassland experiments. It addressed the following questions: 1) What is the strength of correlation between herbage DM yields and the yearly amount of precipitation, and between herbage DM yields and the amounts of precipitation during the growing seasons? 2)Is there an interaction between the year and the treatment type (i.e. the cutting frequency in experiment I and the cutting frequencies with different levels fertilization in experiment II? 3) Are the decreases in forage DM yields in years with low total precipitation during the growing season equal in all management treatments? 4) Are the reductions in forage DM yields in years with one or two months of very low precipitation during March-August equal in all the management treatments? 5) Are the increases in forage DM yields in years after low precipitation years equal in all of the management treatments?

\section{Materials and methods}

The field experiments were set up in 1995 on the semi-natural wet grassland of creeping buttercup and meadow foxtail plant community (Ranunculo repentis and Alopecuretum pratensis) (Ellmauer, Mucina, 1993), south of Maribor, Slovenia (46 $28^{\prime} 16^{\prime \prime} \mathrm{N}, 15^{\circ} 38^{\prime} 20^{\prime \prime} \mathrm{E}$, 300 m a.s.1.) on Dystric Cambisol (CMd) (FAO, 1989), with a soil $\mathrm{pH}\left(\mathrm{CaCl}_{2}\right)$ of $5.9,9.2 \mathrm{mg}$ ammonlactatesoluble $\mathrm{P}_{2} \mathrm{O}_{5}$, and $21.2 \mathrm{mg}$ ammonlactate-soluble $\mathrm{K}_{2} \mathrm{O}$ $100 \mathrm{~g}^{-1}$ air-dried soil (Egnér et al., 1960).

The yearly mean air temperature in the region during the experiments in $1995-2012$ was $10.7^{\circ} \mathrm{C}$, the monthly mean air minimum was $0.1^{\circ} \mathrm{C}$ in January, and the mean monthly maximum in July was $21.1^{\circ} \mathrm{C}$ (ARSO, 2013). During 1995-2012, the average annual rainfall in the area was $954 \mathrm{~mm}$. In the region, the growing season begins in late March and lasts until late October. Precipitation is, on average, relatively equally distributed during the whole year, with more precipitation during the growing season (Table 1). However, the weather is very changeable. In particular, precipitation varies from year to year, with high amounts of monthly precipitation in one year and small amounts of precipitation (drought) in the same month of another year (Kramberger, Kaligarić, 2008). The experiments were carried out on slope terrain where, even in very wet years the level of ground water cannot influence the growth of grassland plants.

Table 1. Total precipitation and average air temperatures during the observation period (ARSO, 2013)

\begin{tabular}{|c|c|c|c|c|c|c|c|c|c|c|c|c|c|c|}
\hline \multirow{2}{*}{ Month } & \multicolumn{13}{|c|}{ Year } & \multirow{2}{*}{ Average } \\
\hline & 2000 & 2001 & 2002 & 2003 & 2004 & 2005 & 2006 & 2007 & 2008 & 2009 & 2010 & 2011 & 2012 & \\
\hline \multicolumn{15}{|c|}{ Precipitation $\mathrm{mm}$} \\
\hline January & 11 & 80 & 9 & 46 & 63 & 11 & 44 & 47 & 2 & 97 & 35 & 19 & 10 & 36 \\
\hline February & 18 & 2 & 51 & 28 & 33 & 46 & 32 & 45 & 28 & 44 & 45 & 10 & 19 & 31 \\
\hline March & 45 & 86 & $34 *$ & $5 *$ & 88 & $39 *$ & 53 & 102 & 106 & 74 & $17^{*}$ & 39 & $5^{*}$ & 53 \\
\hline April & 50 & 77 & 110 & $45^{*}$ & 77 & 97 & 76 & $5^{*}$ & $44^{*}$ & 51 & 55 & 53 & 56 & 61 \\
\hline May & $62 *$ & 80 & $46^{*}$ & $49 *$ & $55^{*}$ & 81 & 136 & 104 & 73 & 144 & 68 & 85 & 124 & 85 \\
\hline June & $41 *$ & 112 & 78 & $25^{*}$ & 219 & $38 *$ & 104 & 75 & 148 & 136 & 104 & 122 & 88 & 99 \\
\hline July & 101 & $40 *$ & $74 *$ & 78 & $70 *$ & 203 & $60 *$ & 103 & 144 & $70 *$ & 81 & 134 & 126 & 99 \\
\hline August & $37 *$ & $38 *$ & 181 & $45^{*}$ & 87 & 168 & 192 & 115 & 130 & 200 & 174 & $56^{*}$ & $36^{*}$ & 112 \\
\hline September & 82 & 189 & 74 & 143 & 91 & 116 & 101 & 217 & 50 & 94 & 220 & 46 & 153 & 121 \\
\hline October & 136 & 47 & 99 & 124 & 124 & 10 & 39 & 84 & 52 & 44 & 52 & 101 & 154 & 82 \\
\hline November & 125 & 57 & 49 & 69 & 48 & 83 & 45 & 32 & 61 & 64 & 95 & 0 & 97 & 63 \\
\hline December & 86 & 21 & 114 & 34 & 39 & 67 & 22 & 54 & 105 & 60 & 40 & 65 & 46 & 58 \\
\hline Year & 794 & 829 & 919 & 691 & 994 & 959 & 904 & 983 & 943 & 1078 & 986 & 730 & 915 & 902 \\
\hline $\begin{array}{l}\text { March- } \\
\text { August }\end{array}$ & 336 & 433 & 523 & 247 & 596 & 626 & 621 & 504 & 645 & 675 & 499 & 489 & 434 & 510 \\
\hline \multicolumn{15}{|c|}{ Temperature ${ }^{\circ} \mathrm{C}$} \\
\hline Year & 11.4 & 10.5 & 11.3 & 10.6 & 9.9 & 9.5 & 10.2 & 11.1 & 11.1 & 10.8 & 10.1 & 10.8 & 11.2 & 10.7 \\
\hline $\begin{array}{l}\text { March- } \\
\text { October }\end{array}$ & 15.7 & 15.1 & 15.1 & 15.7 & 14.1 & 14.1 & 14.7 & 15.1 & 14.9 & 15.2 & 14.4 & 15.3 & 15.9 & 15.0 \\
\hline
\end{tabular}

Note. The values marked with * represent 1 - or 2 -month periods with less than $75 \%$ precipitation compared to the average. 
The experimental design used for both experiments was a randomized complete block with four replications. The individual plot size in experiment I was $2 \times 5 \mathrm{~m}$, in experiment II it was $5 \times 8 \mathrm{~m}$. The individual plots were surrounded by paths $1 \mathrm{~m}$ wide, cut once per month. In experiment I, the management treatment was different cutting frequencies: treatment 1 - first cut in the middle of April, cuts at two-week intervals, 12-14 cuts per year; treatment 2 - first cut at the end of April, cuts at four-week intervals, six cuts per year; treatment 3 first cut in the middle of May, cuts at six-week intervals, four cuts per year; treatment 4 - first cut at the end of May, cuts at eight-week intervals, three cuts per year; treatment 5 - first cut in the middle of June, cuts at 10week intervals, two cuts per year; treatment 6 - first cut at the end of June, cuts at 12-week intervals, two cuts per year. All the plots received $180 \mathrm{~kg} \mathrm{~N}$ (in the years 1995-2000) and $170 \mathrm{~kg} \mathrm{~N}$ (in the years 2001-2012), $40 \mathrm{~kg} \mathrm{P}$ and $150 \mathrm{~kg} \mathrm{~K}$ year $^{-1}$. In experiment II treatment 1 , the first cut was in the middle of May, and the cuts were at six-week intervals, with four cuts per year. The fertilization was the same as in experiment I. In treatment 2 , the first cut was in mid-June, and the second cut was at the end of August (two cuts per year). The fertilization was $35 \mathrm{~kg} \mathrm{P}$ and $100 \mathrm{~kg} \mathrm{~K}$ year ${ }^{-1}$. For estimating the dry matter (DM) yield, the plots were cut to a stubble height of $5 \mathrm{~cm}$, and the samples of yields of each cut and each plot were dried at $70^{\circ} \mathrm{C}$ in a forced-draught oven. The botanical composition of the samples was determined by the direct estimation technique, done by three estimators (Mannetje, Jones, 2000).

To try to avoid the effect of intensive changes in the botanical composition in the first years of the experiments only the annual DM yields during 20002012 were included in the present study. Therefore, at the beginning of the observation period, the treatments had already consisted of for the treatment-specific botanical composition, which was the result of five years of adaptation (Table 2).

Table 2. Botanical composition at the beginning of the experiments (1995), in the year before the observation period (1999), and in the year of the end of the observation period (2012)

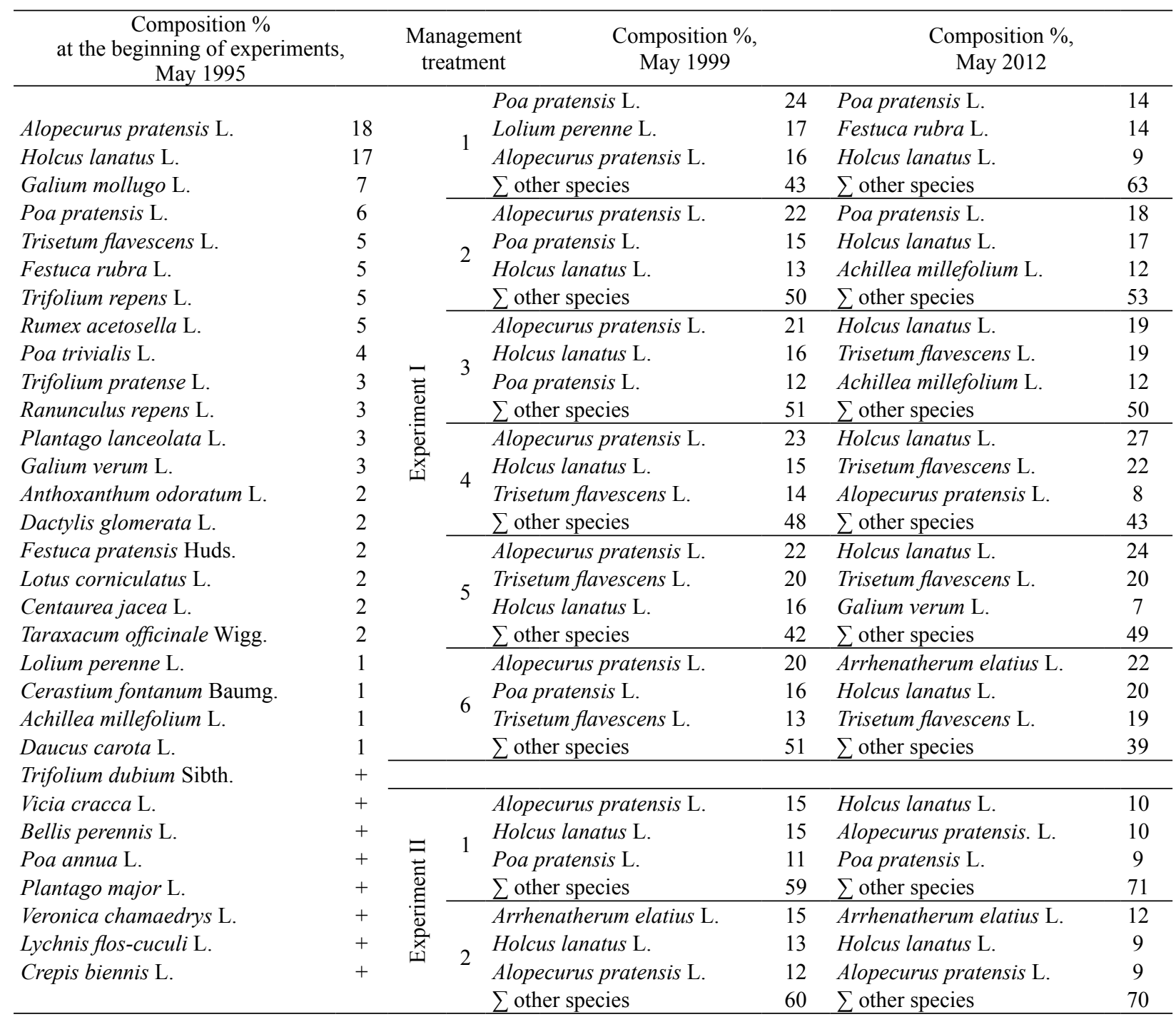

Notes. Experiment I: 1 - cuts at 2-week intervals, 2 - cuts at 4-week intervals, 3 - cuts at 6 -week intervals, 4 - cuts at 8 -week intervals, 5 - cuts at 10-week intervals, 6 - cuts at 12-week intervals; experiment II: treatment 1 - the first cut in the middle of May, and the cuts were at 6-week intervals, treatment 2 - the first cut in mid-June, and the second cut at the end of August. + - plant species is sparse and covers a small area. 
Calculations and statistical analysis. Pearson correlation coefficient $(r)$ provided a means for estimating correlations between annual herbage DM yields and meteorological parameters. The effects of the management treatment (factor A) and the year (factor B) on the forage DM yield were analyzed for each experiment separately using a two-way $A N O V A$. Due to a significant management treatment $\times$ year interaction, the effects of a low rainfall growing season and low rainfall periods during the growing season on the herbage productivity of the mesic semi-natural grasslands under the different management treatments were analyzed in more detail. For this purpose, we selected all one- and two-month-periods within March-August with less than $75 \%$ of rainfall, on average, than during the 2000-2012 observation period (Table 2). According to the selected low rainfall periods, three comparisons of the average annual DM yields of four low and high precipitation periods were analyzed using ANOVA (Table 3). Means were separated using Fisher's LSD test. Statistical significance was evaluated at $P \leq 0.05$.

Table 3. Comparisons subjected to statistical analysis

\begin{tabular}{ccc}
\hline \multirow{2}{*}{ Comparison } & \multicolumn{2}{c}{ Comparing group of selected years } \\
\hline \multirow{2}{*}{ I } & $\mathrm{X}(2005,2006$, & $\mathrm{Y}(2000,2001$, \\
& $2008,2009)$ & $2003,2012)$ \\
II & $\mathrm{X}(2006,2007$, & $\mathrm{Y}(2000,2001$, \\
& $2008,2009)$ & $2002,2003)$ \\
III & $\mathrm{X}(2000,2001$, & $\mathrm{Y}(2004,2005$, \\
& $2002,2003)$ & $2006,2007)$ \\
\hline
\end{tabular}

Note. Comparison/comparing groups: $\mathrm{I} / \mathrm{X}=$ the average annual herbage DM yield of years with the highest amounts of rainfall during the March-August period, $\mathrm{I} / \mathrm{Y}=$ the average annual herbage DM yield of years with the lowest amounts of precipitation during the March-August period; II/X = the average annual herbage DM yield of years with the least of one or two months periods with less than $75 \%$ of the average precipitation in 2000-2012 during the March-August period, $\mathrm{II} / \mathrm{Y}=$ the average annual herbage DM yield of years with the most of one or two months periods with less than $75 \%$ of the average precipitation in 2000-2012 during the March-August period; III/X = the average annual herbage DM yield of four consecutive years with low precipitation during the MarchAugust period, III/Y = the average annual DM yield of the next consecutive four years with high precipitation during the March-August period.

\section{Results and discussion}

Taking into account the findings of Walter et al. (2012), the correlations between meteorological data and annual overall management treatments' average herbage DM yields were as expected (Table 4). They indicated that higher correlations existed when meteorological data from growing periods only, not yearly, were taken into consideration (i.e. precipitation during the March-August period and average temperature during the March-October period). Consequently, all further analyses of the influences of years include these data, but not yearly precipitation and temperature (Tables
5-7, Fig.). The average temperature during the MarchOctober period and the amount of precipitation during the March-August period in both experiments show nearly the same high positive correlations with annual herbage DM yields (Table 4). However, high negative correlations were found between the amounts of precipitation and average temperatures, which is consistent with some other studies (Trenberth, Shea, 2005; Cong, Brady, 2012). Wet summers with cloudy skies are cooler than dry summers with more sunshine and less evaporative cooling. The observed correlation led to the use of the phrase "a period" with a low or high amount of precipitation under which, hereinafter, characteristics of accompanying meteorological elements (e.g., lower temperature accompanies more rainfall) are included.

Table 4. The correlations among meteorological parameters and annual overall treatments' average herbage dry matter (DM) yields

\begin{tabular}{|c|c|c|c|c|}
\hline & $\begin{array}{l}\text { Yearly } \\
\text { precipi- } \\
\text { tation }\end{array}$ & $\begin{array}{l}\text { Precipi- } \\
\text { tation } \\
\text { during } \\
\text { March- } \\
\text { August } \\
\text { period }\end{array}$ & $\begin{array}{l}\text { Average } \\
\text { yearly } \\
\text { tempera- } \\
\text { ture }\end{array}$ & $\begin{array}{c}\text { Average } \\
\text { temperature } \\
\text { during } \\
\text { March- } \\
\text { October } \\
\text { period }\end{array}$ \\
\hline $\begin{array}{l}\text { Annual herbage } \\
\text { DM yield in } \\
\text { experiment I }\end{array}$ & $\begin{array}{c}0.314 * \\
(0.005)^{* *}\end{array}$ & $\begin{array}{c}0.497 \\
(0.000)\end{array}$ & $\begin{array}{l}-0.377 \\
(0.001)\end{array}$ & $\begin{array}{l}-0.515 \\
(0.000)\end{array}$ \\
\hline $\begin{array}{l}\text { Annual herbage } \\
\text { DM yield in } \\
\text { experiment II }\end{array}$ & $\begin{array}{c}0.485 \\
(0.012)\end{array}$ & $\begin{array}{c}0.697 \\
(0.001)\end{array}$ & $\begin{array}{l}-0.585 \\
(0.002)\end{array}$ & $\begin{array}{l}-0.742 \\
(0.000)\end{array}$ \\
\hline $\begin{array}{l}\text { Yearly } \\
\text { precipitation }\end{array}$ & & $\begin{array}{c}0.774 \\
(0.000)\end{array}$ & $\begin{array}{l}-0.212 \\
(0.062)\end{array}$ & $\begin{array}{l}-0.535 \\
(0.000)\end{array}$ \\
\hline $\begin{array}{l}\text { Precipitation } \\
\text { during March- } \\
\text { August period }\end{array}$ & & & $\begin{array}{l}-0.339 \\
(0.002)\end{array}$ & $\begin{array}{l}-0.658 \\
(0.000)\end{array}$ \\
\hline $\begin{array}{l}\text { Average yearly } \\
\text { temperature }\end{array}$ & & & & $\begin{array}{c}0.804 \\
(0.000)\end{array}$ \\
\hline
\end{tabular}

* - Pearson correlation coefficient, $* *-P$-value

In all management treatment cases of both experiments, the results produced high positive correlations between the amounts of precipitation during March-August periods and the annual herbage DM yields, which agrees with the findings of Gilgen and Buchmann (2009) that showed a strong relationship between the average annual aboveground grassland biomass and the total annual precipitation in Switzerland. In the experiments presented here, statistically significant coefficients were between 0.609, for the two-cut treatment in experiment I, and 0.872 , for the four-cut treatment in experiment II. Moreover, the results in Table 5 show that, with the increasing number of cuts per year, the correlation coefficient $(r)$ between the amount of precipitation and the herbage DM yield increased as did the statistical significance of the correlation (lowering of $P$-value). The obtained results prove a higher dependence of herbage DM yields on the amount of precipitation and the accompanying weather characteristics for intensive mesic grasslands with more cuts per year than for grasslands with extensive two-cut management systems. 
Table 5. The correlation $(r)$ between annual herbage dry matter yields and the amount of precipitation during MarchAugust periods for individual management treatments

\begin{tabular}{cccc}
\hline \multirow{2}{*}{$\begin{array}{c}\text { Management treatment } \\
\text { cuts year }\end{array}$} & \multicolumn{2}{c}{$\begin{array}{c}\text { The precipitation during } \\
\text { March-August period }\end{array}$} \\
\cline { 2 - 4 } & $1(12-14)$ & 0.795 & 0.001 \\
& $2(6)$ & 0.788 & 0.001 \\
Experiment I & $3(4)$ & 0.758 & 0.003 \\
& $4(3)$ & 0.724 & 0.005 \\
& $5(2)$ & 0.609 & 0.027 \\
& $6(2)$ & 0.620 & 0.024 \\
\hline \multirow{2}{*}{ Experiment II } & $1(4)$ & 0.872 & 0.000 \\
& $2(2)$ & 0.695 & 0.008 \\
\hline
\end{tabular}

* - Pearson correlation coefficient

The analysis of variance of the data for the period 2000-2012 showed that the management treatment and the year significantly affected the herbage DM yield in both experiments, although the $F$-value for the year was lower than for the management treatment (Table 6). The management treatment $\times$ year significant interaction confirmed the different responses of the individual treatments to changes in the weather characteristics during the growing season of the observed years (Table 6).

The average annual herbage DM yield for the entire observation period in experiment $\mathrm{I}$ in which all the treatments received the same amount of fertilizers increased in accordance with a decrease in the cutting frequency (Table 7). Statistically, the lowest yield was obtained with treatment $1\left(4.86 \mathrm{t} \mathrm{ha}^{-1}\right)$ and the highest was obtained with treatments 4,5 and $6(9.31,8.82$ and $9.09 \mathrm{t} \mathrm{ha}^{-1}$, respectively). This result is in agreement with a previous study (Bernhardt-Römermann et al., 2011) that predicted the highest herbage yields in treatments with two cuts per year. In experiment II, the average annual yield in treatment 1 (four cuts per year) was higher $\left(7.63 \mathrm{tha}^{-1}\right)$ than in treatment 2 (two cuts per year) $\left(5.91 \mathrm{t} \mathrm{ha}^{-1}\right)$ as was expected due to the higher amount of fertilizers added in management treatment 1 .

Table 6. The analysis of variance for effects of the management treatment and the year on herbage dry matter yield

\begin{tabular}{ccccccc}
\hline & \multicolumn{3}{c}{ Experiment I } & \multicolumn{3}{c}{ Experiment II } \\
\cline { 2 - 7 } Source & $\begin{array}{c}\text { Degrees of } \\
\text { freedom }\end{array}$ & F-value & $P$-value & $\begin{array}{c}\text { Degrees of } \\
\text { freedom }\end{array}$ & F-value & $P$-value \\
\hline Management treatment (factor A) & 5 & 296.15 & 0.0000 & 1 & 321.32 & 0.0000 \\
Year (factor B) & 12 & 125.84 & 0.0000 & 12 & 93.67 & 0.0000 \\
A $\times$ B & 60 & 6.77 & 0.0000 & 12 & 14.08 & 0.0000 \\
Residual & 231 & & & 75 & & \\
\hline
\end{tabular}

Table 7. Average annual herbage dry matter (DM) yields according to the management treatment in experiments I and II, and the results of three comparisons

\begin{tabular}{|c|c|c|c|c|c|c|}
\hline & \multirow{3}{*}{$\begin{array}{c}\text { Management } \\
\text { treatment } \\
\text { cuts year }^{-1}\end{array}$} & \multirow{3}{*}{$\begin{array}{l}\text { Average DM yield } \\
\text { t ha }^{-1} \text { per year* }\end{array}$} & \multirow{3}{*}{ Comparing group } & \multicolumn{3}{|c|}{ Comparison } \\
\hline & & & & $\mathrm{I}$ & II & III \\
\hline & & & & \multicolumn{3}{|c|}{$\begin{array}{l}\text { Average DM yield } \\
\text { t ha }^{-1} \text { per year** }\end{array}$} \\
\hline \multirow{14}{*}{ 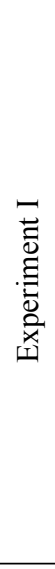 } & \multirow{2}{*}{$1(12-14)$} & \multirow{2}{*}{$4.86 \mathrm{~d}$} & $\mathrm{X}$ & $5.81 \mathrm{~d}$ & $5.65 \mathrm{~d}$ & $3.86 \mathrm{~g}$ \\
\hline & & & $\mathrm{Y}$ & $3.84 \mathrm{e}$ & $3.86 \mathrm{e}$ & $5.69 \mathrm{f}$ \\
\hline & \multirow{2}{*}{$2(6)$} & \multirow{2}{*}{$6.81 \mathrm{c}$} & $\mathrm{X}$ & $8.07 \mathrm{bc}$ & $7.95 \mathrm{c}$ & $5.56 \mathrm{f}$ \\
\hline & & & $\mathrm{Y}$ & $5.48 \mathrm{~d}$ & $5.56 \mathrm{~d}$ & 8.14 ed \\
\hline & \multirow{2}{*}{$3(4)$} & \multirow{2}{*}{$7.81 \mathrm{~b}$} & $\mathrm{X}$ & $8.41 \mathrm{~b}$ & $8.41 \mathrm{bc}$ & $6.25 \mathrm{f}$ \\
\hline & & & $\mathrm{Y}$ & $6.11 \mathrm{~d}$ & $6.24 \mathrm{~d}$ & $9.14 \mathrm{~cd}$ \\
\hline & \multirow{2}{*}{$4(3)$} & \multirow{2}{*}{$9.31 \mathrm{a}$} & $\mathrm{X}$ & $10.48 \mathrm{a}$ & $10.28 \mathrm{a}$ & 8.39 ed \\
\hline & & & $\mathrm{Y}$ & $7.92 \mathrm{bc}$ & $8.39 \mathrm{bc}$ & $10.78 \mathrm{ab}$ \\
\hline & \multirow{2}{*}{$5(2)$} & \multirow{2}{*}{$8.82 \mathrm{a}$} & $\mathrm{X}$ & $9.59 \mathrm{a}$ & $8.70 \mathrm{bc}$ & $7.84 \mathrm{e}$ \\
\hline & & & $\mathrm{Y}$ & $7.29 \mathrm{c}$ & $7.84 \mathrm{c}$ & $9.97 \mathrm{bc}$ \\
\hline & \multirow{2}{*}{$6(2)$} & \multirow{2}{*}{$9.09 \mathrm{a}$} & $\mathrm{X}$ & $10.26 \mathrm{a}$ & $9.47 \mathrm{ab}$ & $8.04 \mathrm{e}$ \\
\hline & & & $\mathrm{Y}$ & $7.80 \mathrm{bc}$ & $8.04 \mathrm{c}$ & $11.07 \mathrm{a}$ \\
\hline & & Average $X$ & & $8.77 \mathrm{a}$ & $8.41 \mathrm{a}$ & $6.66 \mathrm{~b}$ \\
\hline & & Average $\mathrm{Y}$ & & $6.41 \mathrm{~b}$ & $6.65 \mathrm{~b}$ & $9.23 \mathrm{a}$ \\
\hline \multirow{6}{*}{ 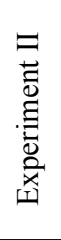 } & \multirow{2}{*}{$1(4)$} & \multirow{2}{*}{$7.63 \mathrm{a}$} & $\mathrm{X}$ & $9.13 \mathrm{a}$ & $8.50 \mathrm{a}$ & $6.27 \mathrm{c}$ \\
\hline & & & $\mathrm{Y}$ & $5.94 \mathrm{c}$ & $6.27 \mathrm{~b}$ & $9.11 \mathrm{a}$ \\
\hline & \multirow{2}{*}{$2(2)$} & \multirow{2}{*}{$5.91 \mathrm{~b}$} & $\mathrm{X}$ & $6.82 \mathrm{~b}$ & $6.18 \mathrm{~b}$ & $4.12 \mathrm{~d}$ \\
\hline & & & $\mathrm{Y}$ & $3.93 \mathrm{~d}$ & $4.12 \mathrm{c}$ & $7.91 \mathrm{~b}$ \\
\hline & & Average $X$ & & $7.98 \mathrm{a}$ & $7.34 \mathrm{a}$ & $5.20 \mathrm{~b}$ \\
\hline & & Average $\mathrm{Y}$ & & $4.94 \mathrm{~b}$ & $5.19 \mathrm{~b}$ & $8.51 \mathrm{a}$ \\
\hline
\end{tabular}

Notes. The management treatment abbreviations are under Table 2. The comparison/comparing group abbreviations are under Table 3. * - average for 2000-2012, ** - average annual herbage DM yield of the four selected years from period 2000-2012 (Table 3). Numbers followed by a different letter within a column and a set are significantly different $(P \leq 0.05)$ according to the LSD test. 
In comparison I, the decrease in average annual DM yield of four years with the lowest amounts of precipitation during March-August in comparison to four years with the highest amounts of rainfall during MarchAugust period was proved for all management treatments in both experiments (Table 7). However, the decrease in experiment $I$ is higher in treatments with higher cutting frequencies (treatments 1,2 and 3), than in treatments with two cuts per season (treatments 5 and 6) (Fig.). On the contrary, in experiment II higher decrease is obtained in annually two cut treatment 2 , than in four cut treatment 1 (Fig.). Similar results are obtained in comparison II, in which the decrease in average annual DM yield of four years with the most of one or two months periods with less than 75\% precipitation of the average 2000-2012 during March-August period is compared the yield of four years with the least of one or two months periods with less than $75 \%$ precipitation of the average 2000 2012 during March-August period (Table 7, Fig.).

The different reductions in the herbage yields with the individual management treatments may be attributed to the differences in the botanical composition of treatments and, consequently, as reported by some authors (Kreyling et al., 2008; Swemmer, Knapp, 2008; Jentsch et al., 2009) to the different responses of the different plant communities to low amounts of available water (Table 2). On the other hand, in treatments with low cutting frequencies, the duration from the beginning of growth to the cutting date in many cases allows plants to absorb more water before or after the drought period. The plants in the treatments with high cutting frequencies (cuts every two or four weeks) would not be able to do this. Consequently, as stated earlier (Bernhardt-Römermann et al., 2011), the relative importance of precipitation is expected to be greater at high cutting frequencies. This was found only in experiment I, in which all the treatments received the same amount of fertilizers. The fact that the percentage of herbage DM yield was reduced in years with low precipitation in the treatment with the four cuts in experiment II compared with the two cuts treatment is in agreement with earlier findings (Bradford et al., 2006) suggesting that fertilization can overcome the influence of climatic conditions on biomass yield, resulting in more stable productivity.

In comparison III, the increase in the average annual DM yield of four consecutive years with high precipitation during March-August after four consecutive years with low precipitation during the same period was confirmed for all the treatments in both experiments (Table 7). The percentage of increase was higher in experiment $I$ in treatments 1,2 and 3 than in treatments 4, 5 and 6 (Fig.). In experiment II, the percentage increase was higher in treatment 2 than in treatment 1 . The opposite results were obtained in comparisons I and II. The results indicate that treatments with a higher percentage decrease of herbage DM yields in years with low rainfall show a higher percentage increase in herbage DM yields in the following rainfall years. The differences among the treatments in herbage yields could indicate different lag effect of extreme weather events in our treatments; for
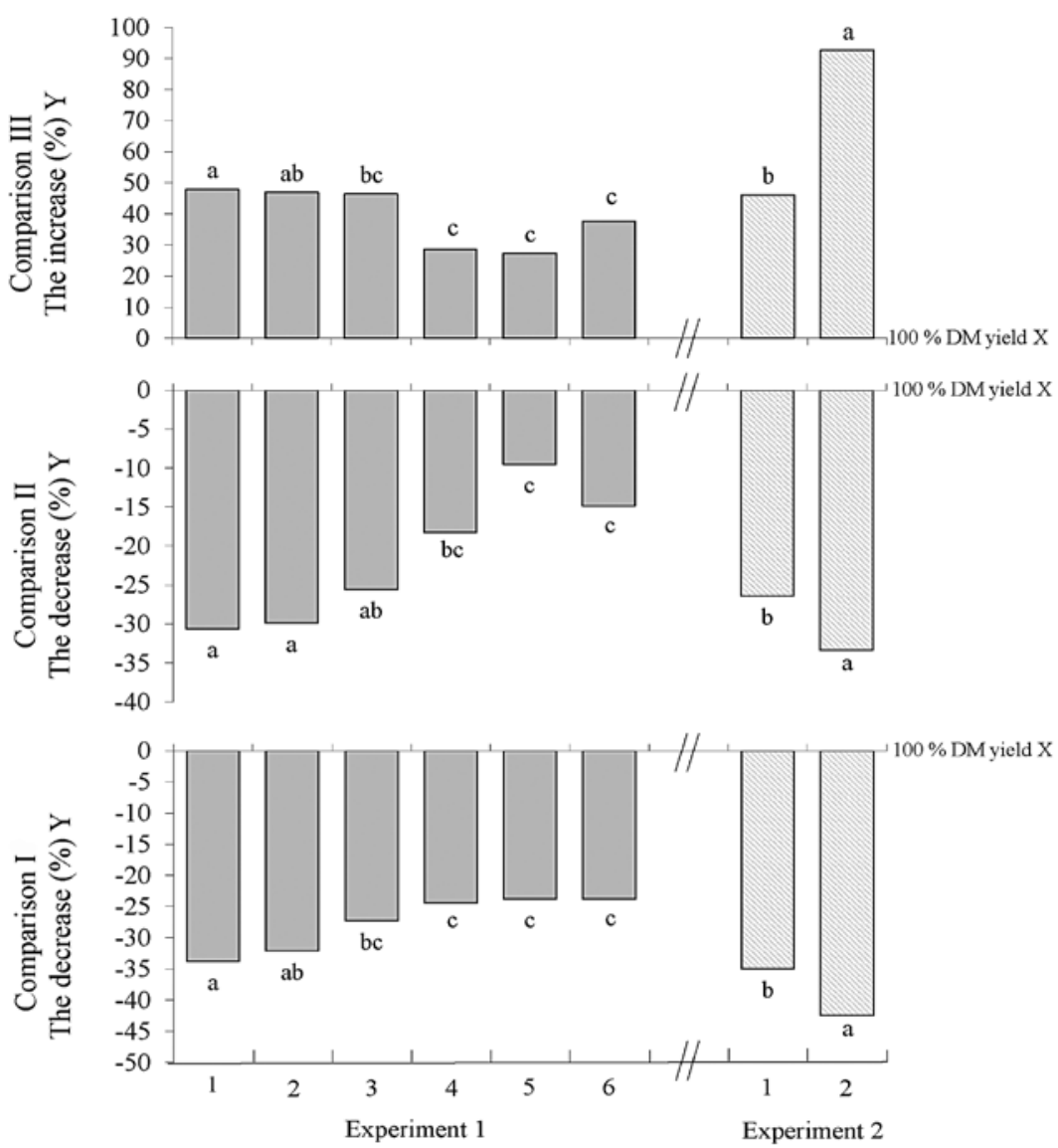

Notes. The management treatment abbreviations are under Table 2; the comparison/comparing group abbreviations are under Table 3. Numbers followed by a different letter within an experiment and a comparison are significantly different $(P \leq 0.05)$ according to the LSD test.

Figure. Decreases or increases in the average annual herbage dry matter (DM) in the analyzed comparisons 
example, different amounts of nutrients in the soil not taken up by plants of individual treatments could influence the herbage DM yield in the next year. The findings about lag effects in herbage yield are reported by Sherry et al. (2008). However, the current experiments could not prove lag effects due to the huge variability in precipitation during all the years of the experimental work.

Semi-natural grasslands as a source of forage for domestic animals should be grazed or repeatedly cut throughout the growing season to obtain highquality forage (Walter et al., 2012). A previous study by Kramberger and Gselman (2000) showed that, in the long-term grassland experiments, the most frequent cuts obtained led to the highest organic matter digestibility, and that digestibility decreased with decreasing cutting frequency. Those findings were in agreement with the results of many chemical analyses (DLG, 1997) of forage produced on grasslands that have proved that only frequent cutting produces higher-quality forage (higher digestibility, energy content, protein content). From a practical point of view, 12-14 cuts per year (treatment 1 in experiment I) is too many, and 2 cuts per year with high amounts of added $\mathrm{N}$ fertilizers (experiment $\mathrm{I}$ ) are too few for profitable livestock production. However, these treatments were included in the study to see grassland reaction to the changes in management. Nevertheless, for farmers who need high-quality forage for animals, the obtained results of experiment I proved that the increased cutting frequency cannot buffer the negative effects of low precipitation, if more frequent cutting of mesic grasslands is not accompanied by high applications of fertilizers which is demonstrated in experiment II. The current results obtained in experiments where the mean annual rainfall was $954 \mathrm{~mm}$, like those obtained by Bernhardt-Römermann et al. (2011) in experiments carried out in areas with $635 \mathrm{~mm}$ mean annual rainfall, indicate that extremes in grassland management are the worst solutions for farmers. Extremely low cutting frequency results in the production of low quality forage and extremely high cutting frequency results not only in lower yields but also in very high yield dependence on regular rainfall. Nevertheless, despite demonstrating the beneficial effects of the various treatments on the DM yields, the buffering effects on herbage DM yields in the current experiments were too weak to overcome the negative effects of low precipitation, pointing to the need for further research. In managing existing mesic grassland areas, to overcome the lack of forage during and after drought periods, livestock farmers should adopt flexible management practices, including measures such as using reserve sectors for forage production, buying additional forage, producing more forage in wet periods, and storing this forage (Nettier et al., 2012).

\section{Conclusions}

1. The amount of annual herbage dry matter(DM) yield correlated highly with the amount of precipitation during the March-August period. The correlation was stronger for management with high cutting frequencies.

2. The current experiments revealed significant variation in the responses of mesic grassland herbage DM yields to different management treatments in the presence of precipitation variation across different growing seasons.

3. On average, over the entire observation period, the herbage DM yields of equally fertilized treatments were higher with two cuts than with more cuts per season.

4. During longer periods of low precipitation, the herbage yields with two cuts showed less decrease than did the yields with higher cutting frequencies.

5. Increases in herbage productivity in the years after low-precipitation seasons were greater in the treatments with higher cutting frequencies than in those with two cuts per year.

6. When the four cuts per year treatment received a higher amount of fertilizer than the two cuts per year treatment, the long-term average annual herbage DM yield was higher and the yield was less decreased by longer periods of low precipitation in the four than in the two-cut treatment.

7. Despite confirming the effects of the different treatments on the DM yields and the higher dependency on precipitation of yields resulting from frequent cutting management, the differences among the treatments were not high enough to recommend best-management practices for mesic grassland forage production in areas subject to increased low precipitation periods.

Received 10042013 Accepted 19082013

\section{References}

ARSO. 2013. Climate data archive. The Environmental Agency of the Republic of Slovenia. <http://meteo.arso.gov.si/met/ sl/app/webmet> [accessed 1302 2013]

Beierkuhnlein C., Thiel D., Jentsch A., Willner E., Kreyling J. 2011. Ecotypes of European grass species respond differently to warming and extreme drought. Journal of Ecologv. 99 (3): 703-713 http://dx.doi.org/10.1111/j.1365-2745.2011.01809.x

Bernhardt-Römermann M., Römermann C., Sperlich S., Schmidt W. 2011. Explaining grassland biomass - the contribution of climate, species and functional diversity depends on fertilization and mowing frequency. Journal of Applied Ecology. 48: 1088-1097 http://dx.doi.org/10.1111/j.1365-2664.2011.01968.x

Bloor J. M. G., Pichon P., Falcimagne R., Leadley P., Soussana J.-F. 2010. Effects of warming, summer drought, and $\mathrm{CO}_{2}$ enrichment on aboveground biomass production, flowering phenology, and community structure in an upland grassland ecosystem. Ecosystems. 2010: 888-900 http://dx.doi.org/10.1007/s10021-010-9363-0

Bradford J. B., Lauenroth W. K., Burke I. C., Paruelo J. M 2006. The influence of climate, soils, weather, and land use on primary production and biomass seasonality in the US Great Plains. Ecosystems. 2006: 934-950 http://dx.doi.org/10.1007/s10021-004-0164-1

Cong R.-G., Brady M. 2012. The interdependence between rainfall and temperature: copula analyses. The Scientific World Journal. 11 p. DOI:10.1100/2012/405675 http://dx.doi.org/10.1100/2012/405675

DLG. 1997. Futterwerttabellen Wiederkäuer. Universität Hochenheim. Frankfurt, Germany, 212 p. (in German)

Egnér H., Riehm H., Domingo W. R. 1960. Untersuchungen über die chemische Bodenanalyse als Grundlage für die Beurteilung des Nährstoffzustandes der Böden. II. Chemische Extraktionsmethoden zur Phosphor- und Kaliumbestimmung. Kungliga Lantbrukshögskolans Annaler, 26: 199-215 (in German)

Ellmauer T., Mucina L. 1993. Molinio-Arrhenatheretea. Mucina L. et al. (eds). Die Pflanzengesellschaften Österreich, Teil I. Jena, Austria, p. 297-401 (in German)

FAO. 1989. FAO-UNESCO soils classification system. Food and Agriculture Organization. <http://www.fao. org/docrep/003/Y1899E/y1899e02.htm\#TopOfPage> [accessed 1004 2013] 
Gilgen A. K., Buchmann N. 2009. Response of temperate grasslands at different altitudes to simulated summer drought differed but scaled with annual precipitation. Biogeosciences. 6: 2525-2539 http://dx.doi.org/10.5194/bg-6-2525-2009

Heisler-White J. L., Blair J. M., Kelly E. F., Harmoney K., Knapp A. K. 2009. Contingent productivity responses to more extreme rainfall regimes across a grassland biome. Global Change Biology, 15: 2894-2904 http://dx.doi.org/10.1111/j.1365-2486.2009.01961.x

JentschA., KreylingJ.,Boettcher-TreschkowJ.,Beierkuhnlein C. 2009. Beyond gradual warming: extreme weather events alter flowering phenology of European grassland and heath species. Global Change Biologv. 15 (4): 837-849 http://dx.doi.org/10.1111/j.1365-2486.2008.01690.x

Knapp A. K., Beier C., Briske D. D., Classen A. T., Luo Y., Reichstein M., Smith M. D., Smith S. D., Bell J. E., Fay P. A., Heisler J. L., Leavitt S. W., Sherry R., Smith B., Weng E. 2008. Consequences of more extreme precipitation regimes for terrestrial ecosystems. Bioscience, 58: 811-821 http://dx.doi.org/10.1641/B580908

Kramberger B., Gselman A. 2000. Changes in productivity and botanical composition of semi-natural grassland as a consequence of cutting frequency. Rostlinná výroba, 46: 325-330

Kramberger B., Kaligarić M. 2008. Semi-natural grasslands: the effects of cutting frequency on long-term changes of floristic composition. Polish Journal of Ecology, 56: 33-43

Kreyling J., Wenigmann M., Beierkuhnlein C., Jentsch A. 2008. Effects of extreme weather events on plant productivity and tissue die-back are modified by community composition. Ecosvstems. 11: 752-763 http://dx.doi.org/10.1007/s10021-008-9157-9

MannetjeL.T., Jones R.M.2000.Field andlaboratory methods for grassland and animal production research. Wallingford. UK, 447 p. http://dx.doi.org/10.1079/9780851993515.0000

Nettier B., Dobremez L., Lamarque P., Eveilleau C., Quétier F., Véron F., Lavorel S. 2012. How would farmers in the French Alp adapt their systems to different drought and socio-economic context scenarios? The $10^{\text {th }}$ European
IFSA symposium Producing and Reproducing Farming Systems. <http://ifsa2012.dk/?page_id $=760>$ [accessed $09042013]$

Sherry R. A., Weng E., Arnone J. A., Johnson D. W., Schimel D. S., Verburg P. S., Wallace L. L., Luo Y. 2008. Lagged effects of experimental warming and doubled precipitation on annual and seasonal aboveground biomass production in a tallgrass prairie. Global Change Biologv. 14: 2923-2936 http://dx.doi.org/10.1111/j.1365-2486.2008.01703.x

Swemmer A. M., Knapp A. K. 2008. Defoliation synchronizes aboveground growth of co-occurring $\mathrm{C} 4$ grass species. Ecology. 89: 2860-2867

http://dx.doi.org/10.1890/07-1434.1

Tilman D., Reich P. B., Knops J. M. H. 2006. Biodiversity and ecostystem stability in a decade-long grassland experiment. Nature. 441: 629-632

http://dx.doi.org/10.1038/nature04742

Trenberth K. E., Shea D. J. 2005. Relationship between precipitation and surface temperature. Geophysical Research Letters. 32:L14703 DOI:10.1029/2005GL022760 http://dx.doi.org/10.1029/2005GL022760

Turner C. L., Seastedt T. R., Dyer M. I. 1993. Maximalization of aboveground grassland production - the role of defoliation frequency, intensity, and history. Ecological Applications, 3: 175-186 http://dx.doi.org/10.2307/1941800

Walter J., Grant K., Beierkuhnlein C., Kreyling J., Weber M., Jentsch A. 2012. Increased rainfall variability reduces biomass and forage quality of temperate grassland largely independent of mowing frequency. Agriculture, Ecosystems and Environment. 148: 1-10 http://dx.doi.org/10.1016/j.agee.2011.11.015

Zavolloni C., Gielen B., Lemmens C. M. H. M., De Boeck H. J., Blasi S., Van den Berg S., Nijs I., Cuelemans R. 2008. Does a warmer climate with frequent mild water shortages protect grassland communities against a prolonged drought? Plant and Soil. 308: 119-130

http://dx.doi.org/10.1007/s11104-008-9612-6

Zhang Q., Chen X., Stefan B. 2011. Spatio-temporal variations of precipitation extremes in Yangtze river basin (19602002), China. Atmospheric and Climate Sciences, 1: 1-8

ISSN 1392-3196 / e-ISSN 2335-8947

Zemdirbyste-Agriculture, vol. 101, No. 1 (2014), p. 11-18

DOI $10.13080 /$ z-a.2014.101.002

\title{
Sausringụ laikotarpiụ ịtaka pusiau natūraliụ pievų žoliụ derliui, esant skirtingam pjūčių dažnumui
}

\author{
B. Kramberger, A. Gselman, M. Podvršnik, M. Lešnik, D. Škorjanc
}

Slovènijos Maribor universitetas

\begin{abstract}
Santrauka
Dèl klimato kaitos dažniau susidaro ekstremalios oro sąlygos, kurioms būdingi ilgesni sausringi laikotarpiai, turintys ịtakos pašarų produkcijai pusiau natūraliose pievose. Dviejų ilgalaikių bandymų (2000-2012 m.) metu dažniau pjaunant ir nevienodai tręšiant, tirta sausringų laikotarpiu ịtaka žolių sausujų medžiagų (SM) derliui. Abiejuose bandymuose metinis žoliu sausuju medžiagu derlius stipriai koreliavo su krituliu kiekiu. Koreliacija buvo stipresnè dažniau pjaunant. Pievos priežiūros būdas ir naudojimo metai esmingai veikẻ abiejų bandymų žolès SM derliu. Nustatyta esminè sąveika tarp pievos priežiūros ir metu. Per visą tyrimu laikotarpi žolyną nupjovus du kartus, žolès SM derlius buvo didesnis nei pjaunat dažniau. Be to, ilgesni sausringi laikotarpiai mažiau veikè du kartus pjautų variantų žolių SM derlių, palyginus kai žolè pjauta dažniau. Tačiau žolès derliaus padidèjimas po sausringų sezonų buvo didesnis dažniau pjautų variantu, palyginus su variantais, kai žolė pjauta du kartus per sezoną. Kai keturis kartus per metus pjauta žole patręšta didesniu kiekiu trąšu nei kai pjauta du kartus per metus (antrasis bandymas), ilgalaikis vidutinis žoliụ SM derlius buvo didesnis ir mažiau paveiktas ilgesnių sausringu laikotarpių, palyginus su variantu, kai žole pjauta du kartus per metus. Nors ịvairiu pievos priežiūros būdų ịtaka buvo ịrodyta abiejuose bandymuose, SM skirtumai tarp variantų sausringais metais nebuvo pakankamai dideli, kad būtu galima rekomenduoti geriausias pašarų gamybos priemones pusiau natūraliose pievose tose vietovèse, kuriose vis dažniau kartojasi sausringi laikotarpiai.
\end{abstract}

